EESTI NSV TEADUSTE AKADEEMIA TOIMETISED. 19. KÖIDE KEEMIA * GEOLOOGIA. 1970, Nr. 2

ИЗВЕСТИЯ АКАДЕМНИ НАУК ЭСТОНСКОИ ССР. ТОМ 19 ХИМИЯ * ГЕОЛОГИЯ. 1970 , № 2

\title{
ТРИЛОБИТЫ РОДА ACERNASPIS ИЗ НИЖНЕГО И СРЕДНЕГО ЛЛАНДОВЕРИ ЭСТОНИИ
}

До последнего времени в Эстонин были известны лишь единичные находки представителей рода Acernaspis. Так, Ф. Шмидт (Schmidt, 1881, 1907) отмечает находки «Phacops» elliptifrons из нескольких обнажений Средней Эстонии и одного экземпляра с берегового вала у обнажения Парамая (о. Сааремаа). Хотя эти экземпляры, за исключением одного плохо сохранившегося, утеряны, можно предположить, что они принадлежали нескольким видам.

За последние годы в Эстонии по факопидам накопился новый материал, происходящий главным образом из лландоверийской части кернов буровых скважин. Хотя в этом материале отдельные виды представлены чаше всего единичными экземплярами, большинство из них хорошо сохранилось и приурочено к определенным стратиграфическим уровням. Часть нового материала происходит из обнажений и собрана различными исследователями в течение 1930-1968 гг.

В данной статье описывается пять новых видов рода Acernaspis из относительно глубоководной фации юуруского и райккюлаского горизонтов, а также один вид (Acernaspis sp. а) из полосы выходов (сравнительно мелководная фация юуруского горизонта). Представители данного рода из верхнелландоверийского адавереского горизонта будут описаны в следующей статье автора, где приводится и общий обзор видов рода Acernaspis из лландовери Эстонии и дается сравнение со скандинавским материалом.

При описании нового материала автор придерживается классификации факопид, предложенной недавно К. Кемпбеллом (Campbeli, 1967).

Перед фотографированием экземпляры покрывались хлористым аммонием. Фотографии выполнены автором. Весь описанный материал хранится в Институте геологии АН ЭССР.

Семейство PHACOPIDAE Hawle et Corda, 1847 Подсемейство PHACOPINAE Hawle et Corda, 1847 Род Acernaspis Campbell, 1967

Acernaspis semicircularis sp. n. (табл. I, фиг. $1-5$ ).

Голотип. Головной щит хорошей сохранности, $\operatorname{Tr} 1959$. Нижний лландовери, юуруский горизонт $\left(\mathrm{G}_{1-2}\right)$. Скв. Вильянди, гл. 231,4 м. Единственный экземпляр. 
О п и с ан и е. Умеренно выпуклый головной щит с полукруглым очертанием переднего края и слабо вогнутым задним краем. Спинные борозды прямые, глубокие и широкие, расходятся под углом $55-58^{\circ}$. Борозды глабели четкие. Наружная ветвь передней борозды в виде слабой дуги начинается близко от спинной борозды, перед передним краем глаза. Вғутренняя ветвь слегка загибается назад. Средняя борозда длинная, почти прямая, наружный конец ее находится близко от спинной бороз. ды. Задняя глабельная борозда короткая, широкая, внутренняя ветвь ее наклоняется слегка вперед. Борозды, отделяющие бугорки промежуточного колыца от остальной части его, выражены слабо. Затылочная борозда глубокая; затылочное кольцо широкое (в продольном сечении), приподнято выше глабели. Имеется затылочный бугорок.

Глаза немного сдвинуты назад, высокие, поднимаются выше уровня глабели. Глазные крышки широкие и равномерно дугообразные. Паль пебральная борозда четкая. Зрительная поверхность почти вертикальная и состоит из 21 вертикального ряда глазных линзочек, расположенных по рядам в следующем порядке (начиная спереди): 123434343444434 332 321. Количество глазных линз 64. Они начинаются не у самого подножия глаза, а несколько выше его.

Лицевые швы образуют на щечном поле нерезкий изгиб и соединяются под незначительным углом перед глабелью. Щеки довольно широкие, кончаются короткими щечными шипами. Боковая краевая кайма слабая, передняя кайма выражена более четко. Задняя краевая кайма валиковидная. Задняя краевая борозда разделяет неподвижную щеку на две неровные части (в продольном сечении), из которых задняя несколько шире передней.

Дублюра ровная, гилостомальный шов прямой. Субкранидиальный желоб неглубокий, но четкий по всей дублюре. По бокам желоба встречается 8 зазубрин.

Поверхность головного щита тонкозернистая.

Остальные части спинного щита неизвестны.

Размеры (в мм) приведены в табл. 1.

С равнение. Данный вид строением своих глаз, расположением борозд глабели и некоторыми другими признаками четко отличается от всех других известных видов Acernaspis.

Местон ахождени е. Скв. Вильянди, гл. 231,4 м. Нижний лландсвери, юуруский горизонт $\left(\mathrm{G}_{1-2}\right)$.

\section{Acernaspis estonica sp. n.}

(табл. I, фиг. 6-10).

Голотип. Головной щит, Tr 2472. Нижний лландовери, юуруский торизонт $\left(\mathrm{G}_{1-2}\right)$. Скв. Абья, гл. 310,2 м.

$M$ а тери ал. 2 головных щита, 1 кранидий, 1 свободная щека и 1 раздавленный пигндий. Сохранность в основном хорошая.

О пи с ан и е. Слабо выпуклый головной щит с угловатым передним и вогнутым задним краем. Спинные борозды прямые, широкие, расходятся под углом $58^{\circ}$. Передние борозды глабели не соприкасаются со спинными бороздами. Дистальная ветвь передней борозды в виде слабо вогнутой дуги образует со спинной бороздой угол около $45^{\circ}$, кончается она немного впереди переднего края глаза. Проксимальная ветвь передней борозды вогнута назад. Средняя борозда глабели длинная, почти прямая и расположена перпендикулярно к спинной борозде. Задняя борозда глабели в проксимальной своей части слегка повернута вперед. 
Промежуточное кольцо имеет выступающие бугорки. Затылочная борозда четкая. Затылочное кольцо широкое (в продольном сечении) и умеренно выступающее.

Глаза небольшие, вытянутые от дистальных ветвей передних борозд глабели до ее задних борозд. Глазные крышки широкие, невысокие, не поднимаются до уровня глабели. Пальпебральные борозды четкие. Зрительная поверхность скошена, состоит из 46-48 линз. Линзы располагаются в виде 16 вертикальных рядов, состоящих из 2-4 линз каждый. Количество глазных линз по вертикальным рядам, начиная спереди, следующее:

$\begin{array}{lllllll}\operatorname{Tr} 2472 & 233 & 333 & 343 & 333 & 332 & 2 \\ \operatorname{Tr} 1964 a & 233 & 343 & 343 & 433 & 332 & 2\end{array}$

Линзы начинаются несколько выше подножия глаза.

Лицевые швы образуют на щечном поле довольно закругленный поворот и соединяются впереди глабели под тупым углом.

Щечное поле удлинено, вытянуто назад и кончается под прямым: углом заострением. Боковая краевая кайма отсутствует. Впереди глабели наблюдается узкая предглабельная кайма. Задняя краевая борозда разделяет неподвижную щеку на две равные по ширине части (в продольном сечении).

Дублюра более или менее ровная, гипостомальный шов прямой. По всей дублюре проходит четкий субкранидиальный желоб, боковые части которого имеют 8 зазубрин.

Поверхность головного щита тонкозернистая.

Гипостома и туловище не найдены.

Хвостовой щит вместе с головными щитами не найден. Однако вполне вероятно, что к данному виду принадлежит раздавленный пигидий, найденный в той же скважине на гл. 316,0 м. Әтот пигидий имеет широко округленное очертание. Рахис его состоит из 7-8 колец, из которых первые 4 ясно выражены. Плевральные борозды слабые. Поверхность пигидия тонкозернистая.

С равнение. Acernaspis estonica своеобразной формой глабели, маленькими глазами и удлиненными щеками довольно четко отличается от остальных известных видов Acernaspis.

М ес тон ахожд ен и е. Скв. Абья, интервал $310,2-316,0$ м. Нижний лландовери, юуруский горизонт $\left(\mathrm{G}_{1-2}\right)$.

Acernaspis sulcata sp. n.

(табл. II, фиг. 12-16)

Голотип. Головной щит хорошей сохранности, $\operatorname{Tr} 1958$. Нижний: лландовери, юуруский горизонт $\left(\mathrm{G}_{1-2}\right)$. Скв. Вильянди, гл. 265,0 м.

$M$ a тери ал. Один головной и один неполный хвостовой щит (найдены вместе).

О п и с а и е. Умеренно выпуклый головной щит с угловатым очертанием лобного края. Спинные борозды узкие, очень слабо изогнуты на: ружу, расходятся под углом $-45^{\circ}$.

Борозды глабели четкие. Дистальная ветвь передней борозды в виде слегка загнутой дуги расположена под углом около $45^{\circ} \mathrm{k}$ спинной борозде и почти соприкасается с последней недалеко от переднего края глаза. Проксимальный конец дистальной ветви расширенный. Проксимальная ветвь передней борозды и средняя борозда глабели дугообразные, причем средняя борозда заметно отделена от спинной борозды. 
Затылочная борозда довольно глубокая; затылочное кольцо широкое (в: продольном сечении) и высокое, приподнимается немного выше глабели.

Глаза большие. Глазные крышки узкие с заостренными концами, неравномерно дугообразные (задняя часть крышки загнута сильнее). Глаза немного скошены относительно оси глабели. Пальпебральная б́розда четкая. Зрительная поверхность несколько скошена, носит 102 глазные линзочки, расположенные в 17 вертикальных рядах в следующем порядке (начиная спереди): 456777776776766 43. Подножная часть глаза невысокая.

Щечное поле умеренно широкое, кончается под прямым углом острием. или небольшим шипом. Лицевой шов характеризуется довольно крутым поворотом на щечном поле и значительным углом соединения перед глабелью. Боковая краевая кайма отсутствует. Перед глабелью отмечается узкая, но четкая передняя кайма. Задняя краевая борозда нерезкая, разделяет в продольном сечении неподвижную щеку на две части, из которых задняя часть несколько шире передней.

Дублюра слабо вогнута вверх. Гипостомальный шов прямой. Субкранидиальный желоб сильно выражен по всей дублюре, по бокам имеются зазубрины.

Поверхность головного щита тонкозернистая.

Хвостовой щит имеет 3 плевральные борозды, из них первые 2 умеренно длинные.

Туловнще не найдено.

С ра внение. Описанный вид сходен с Ácernaspis incerta sp. n.. сравнение с которым дано ниже (стр. 163).

М естон ахожден и е. Скв. Вильянди, гл. 265,0 м. Нижний лландовери, юуруский горизонт $\left(\mathrm{G}_{1-2}\right)$.

\section{Acernaspis rectifrons sp. n.}

$$
\text { (табл. II, фиг. 4-11) }
$$

Голоти п. Головной щит, Tr 1965a. Нижний лландовери, райккюлаский горизонт $\left(\mathrm{G}_{3}\right)$, зона Pristiograptus cyphus (по Кальо и Вингисаар, 1969). Скв. Икла, гл. 474,6 м.

М атери ал. Один головной щит, неб́льшой разрушенный кранидий, два хвостовых щита и гипостома. Сохранность хорошая.

О писани е. Умеренно выпуклая глабель обладает почти прямым очертанием лобного края. Спинные борозды довольно глубокие, широкие, расходятся под углом около $48^{\circ}$. Борозды глабели четкие, передние из них не соприкасаются со спинными бороздами. Наружная ветвь передней борозды прямая, начинается перед передним краем глаза и располагается под углом около $45^{\circ}$ к спинной борозде. Проксимальный конец ее расширенный. Внутренняя ветвь передней борозды дугообразная, причем сильнее загнут ее проксимальный конец. Средняя борозда почти прямая, назад загнута только проксимальным своим концом. Задняя борозда глабели довольно узкая и глубокая. Затылочная борозда неглубокая; затылочное кольцо широкое (в продольном сечении).

Глаза умеренной величины, высокие, приподнимаются немного выше уровня глабели. Глазные крышки умеренно широкие, пальпебральныс. борозды четкие. На зрительной поверхности насчитывается 65 глазных линз в 17 вертикальных рядах в следующем порядке (начиная спереди): 34444445444444432 .

Линзы начинаются несколько выше подножия глаза. 
Щечное поле широкое, сильно оттянуто вбок. Щечные шипы имеются, но они, по-видимому, короткие (концы отломаны). Передняя и задняя краевая каймы слабые, боковая кайма не развита. Задняя неглубокая краевая борозда разделяет неподвижную щеку на две почти равные части, из которых передняя часть лишь немного у́же задней.

Лицевой шов характеризуется довольно слабым и расположенным далеко от глаза загибом на щечном поле и почти прямой линией соединения перед глабелью.

Дублюра ровная, гипостомальный шов почти прямой. Субкранидиальный желоб медленно снижается вперед и в самой передней части глабели выражен очень слабо.

Поверхность тонкозернистая, причем зернистость на каймах и дублюре становится более грубой.

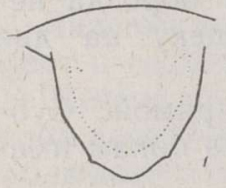

a

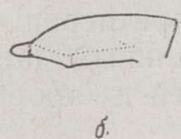

$\delta$.
Acernaspis rectifrons sp. n. Гипостома $(\times 5,5)$ : a - сверху, б- сбоку.

Гипостома (см. рисунок). Передний край немного загнут вперед. Задний край округленно тупоугольного очертания, кончается к бокам двумя маленькими шипами. Имеется боковая кайма, которая при переходе в заднюю кайму несколько расширяется. Макулы нечеткие, расположены в виде слабых желобков вблизи переднего крыла гипостомы под углом оксло $45^{\circ}$ к ее оси. Данная гипостома, очевидно, принадлежит молодой особи.

Хвостовой щит имеет округленное очертание заднего края. Рахис умеренно выпуклый, немного суживается к концу; он довольно длинный, протянут на $4 / 5$ длины пигидия. На рахисе выделяется 4-5 передних колеш, остальные 3-4 остаются нерасчленєнными. На гладкой и плоской плевральной лопасти имеются четыре резкие и довольно длинные (кроме четвертой) плевральные борозды.

С р а в н ен ие. От других видов рода заметно отличается очертанием толовного щита (прямой лобный край, широкие оттянутые вбок щеки), своеобразными бороздами глабели и ослабевающим вперед субкранидиальным желобом.

М ес тон а хожд ен и е. Скв. Икла, интервал $472,8-474,6$ м. Нижний лландовери, райккюлаский горизонт $\left(\mathrm{G}_{3}\right)$, зона Pristiograptus cyphus.

\section{ТАБЛИЦА I}

Фиг. 1-5. Acernaspis semicircularis sp. n. $\times$ 4. Голотип, головной щит, Тr 1959. Скв. Вильянди, гл. 231,4 м, $\mathrm{G}_{1-2} .1$ - сверху; 2 - сбоку; 3 - спереди; 4 - снизу; 5 - вид на щечное поле.

Фиг. 6-10. Acernaspis estonica sp. n. $\times$ 4. Голотип, головной щит, Тr 2472. Скв. Абья, гл. 310,2 м, $\mathrm{G}_{1-2} .6$ - сверху; 7 - сбоку; 8 - спереди; 9 - снизу; 10 - вил на щечное поле.

Фиг. 11-12. Acernaspis sp. b $\times$ 4. Хвостовой щит, Тr 2471, Скв. Лаэва, гл. 136,1 м, $\mathrm{G}_{1-2} .11-$ сверху; $12-$ сзади.

Фиг. 13-15. Acernaspis sp. a $\times$ 4. Пос. Кильтси, $\mathrm{G}_{1-2} .13-$ неполный спинной щит, $\operatorname{Tr} 2483 ; 14$ - туловище с пигидием, $\operatorname{Tr} 2484 ; 15$ - неполный кранидий того же экземпляра. Виды сверху. 

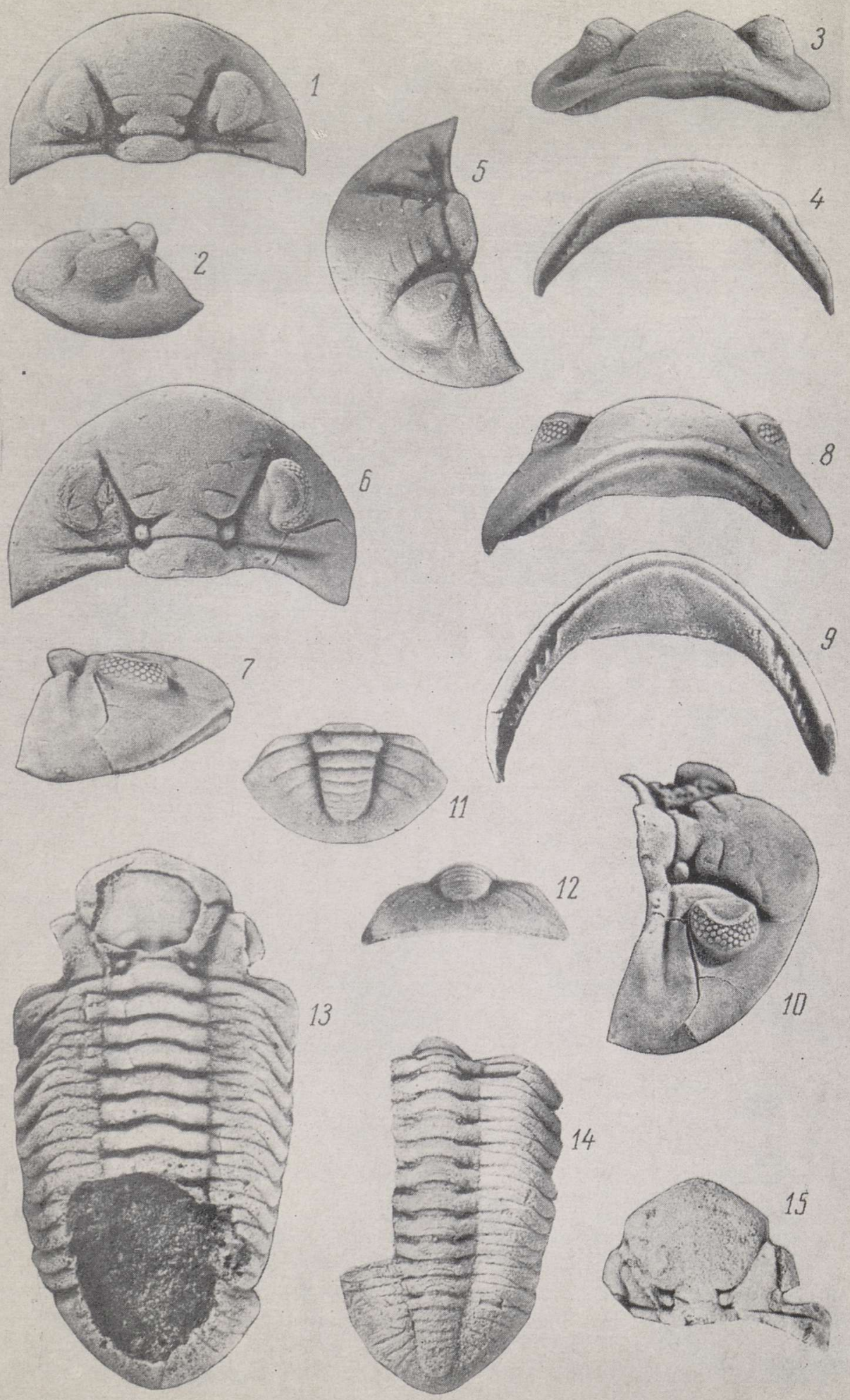

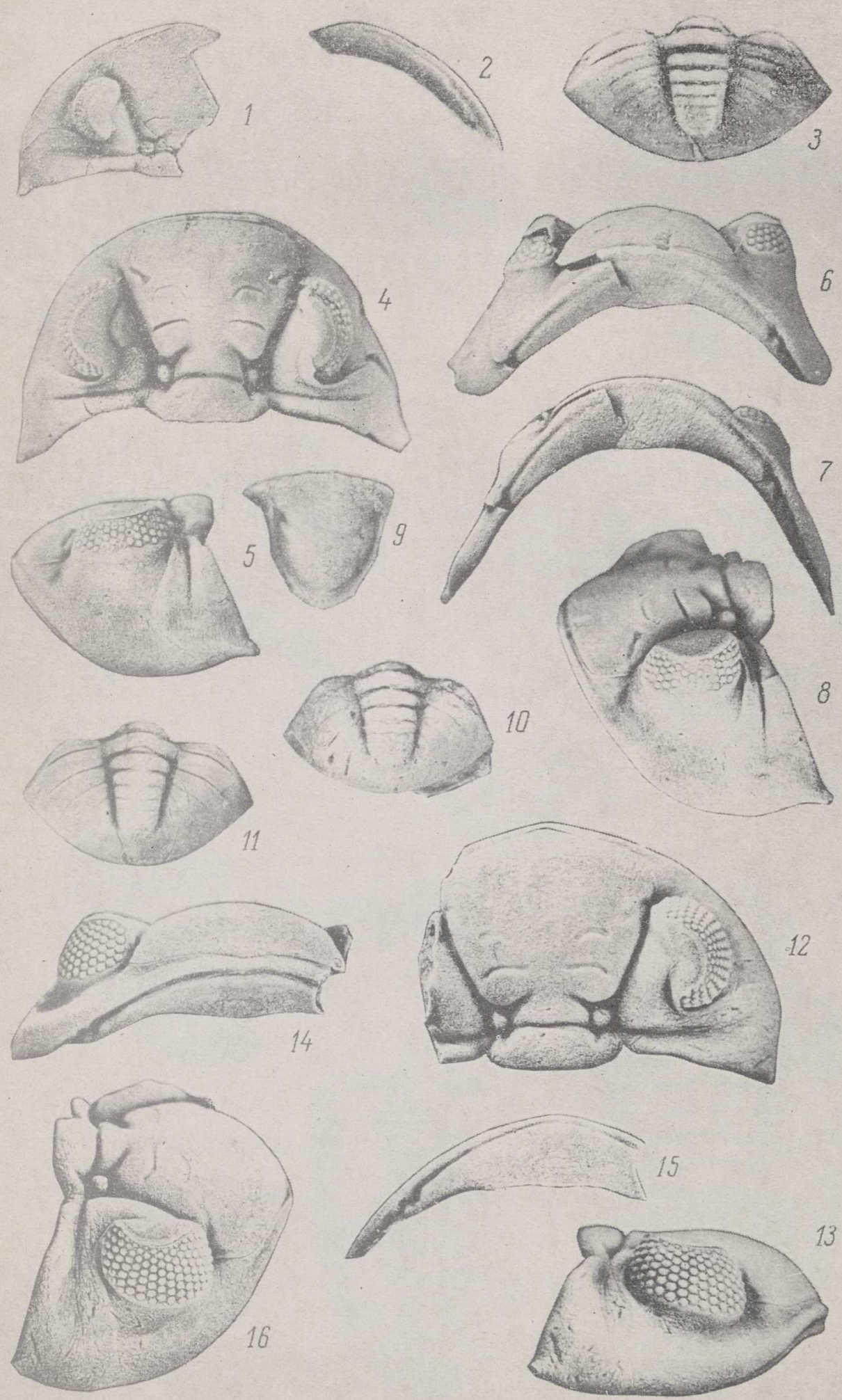
Acernaspis incerta sp. n.

(табл. II, фиг. $1-3$ )

Голоти п. Неполный, слабо сдавленный головной щит, $\operatorname{Tr} 1957 \mathrm{a}$. Средний лландовери, райккюлаский горизонт $\left(\mathrm{G}_{3}\right)$. Скв. Икла, гл. 461,4 .

Матери ал. Неполный головной щит и хвостовой щит. Сохранность средняя.

Опи сание. Головной щит характеризуется слегка угловатым очертанием лобного края. Спинные борозды прямые, расходящиеся под углом около $40^{\circ}$. Борозды глабели слабые. Дистальная ветвь передней борозды прямая, располагается под углом около $30-40^{\circ}$ к спинной борозде и почти соприкасается с ней вблизи переднего края глаза. Проксимальный конец ее раздвоен. Внутренняя ветвь передней борозды дугосбразная. Средняя борозда глабели характеризуется довольно крутой дугой, причем дистальные концы ее больше загнуты назад. Промежуточное и затылочное кольца значительно разрушены, но, по-видимому, не носят специфических для вида признаков.

Глаза умеренной величины. Глазные крышки довольно широкие и равномерно дугообразные. Пальпебральная борозда четкая. Зрительная поверхность скошена, на ней находится 17 вертикальных рядов глазных линзочек в следующем порядке (начиная спереди): 345666 665(?) 665 66 (?) 5 43. Общее количество линз 88.

Щечное поле умеренной ширины. Неподвижная щека кончается коротким щечным шипом. Лицевой шов характеризуется умеренным загибом на щечном поле и заметным углом соединения перед глабелью.

Краевые каймы выражены очень слабо. Задняя краевая борозда нерезкая и разделяет неподвижную щеку на две неровные (в продольном сечении) части, из которых задняя часть несколько шире передней.

Задняя часть дублюры отломана. Субкранидиальный желоб неглубокий, но проходит по всей дублюре; по бокам развиты зазубрины.

Поверхность цефалона тонкозернистая.

Хвостовой щит характеризуется округленным очертанием заднего края. Рахис умеренно выпуклый, слегка суживается к концу и кончается закруглением; вытянут приблизительно на 5/6 длины пигидия. На рахисе четко выделяются 4 передних кольца, задние $4-5$ в основном нерасчлененные. На плевральной лопасти довольно четко выражены 4 плевральные борозды; 3-4 межплевральные борозды выражены очень слабо. Поверхность хвостового щита тонкозернистая.

\section{ТАБЛИЦА ІІ}

Фиг. 1-3. Acernaspis incerta sp. п. × 4. Скв. Икла, гл. 461,4 м, G. $1-2-$ голотип, неполный головной щит, Тг. 1957a: $1-$ сверху; $2-$ снизу; $3-$ хвостовой щит, Tr $1957 \mathrm{~b}$, сверxy.

Фиг. 4-11. Acernaspis rectifrons sp. п. $\times$ 4. $\mathrm{G}_{3} .4-8-$ голотип, головной щит, Tr 1965а, скв. Икла, гл. 474,6 м: 4 - сверху, 5 - сбоку, 6 - спереди, 7 - снизу, 8 вид на щечное поле; 9-10-хвостовой щит и гипостома, Тr 1965b, местонахождение и глубина те же: 9 - гипостома, сверху *, $10-$ хвостовой нит (с гипостомой), сверху; 11 - хвостовой щит, $\operatorname{Tr} 2488$, скв. Икла, гл. 472,8 м, сверху.

Фиг. 12-16. Acernaspis sulcata sp. п. $\times$ 4. Голотип, Тr 1958, неполный головной щит. Скв. Вильянди, гл. 265,0 м, $\mathrm{G}_{1-2} \cdot 12-$ сверху; $13-$ сбоку; 14 - спередн; 15 - снизу; 16 - вид на щечное поле.

* Дано в $\times 6$ увеличении.

5 ENSV TA Toimetised K* G-2 1970 


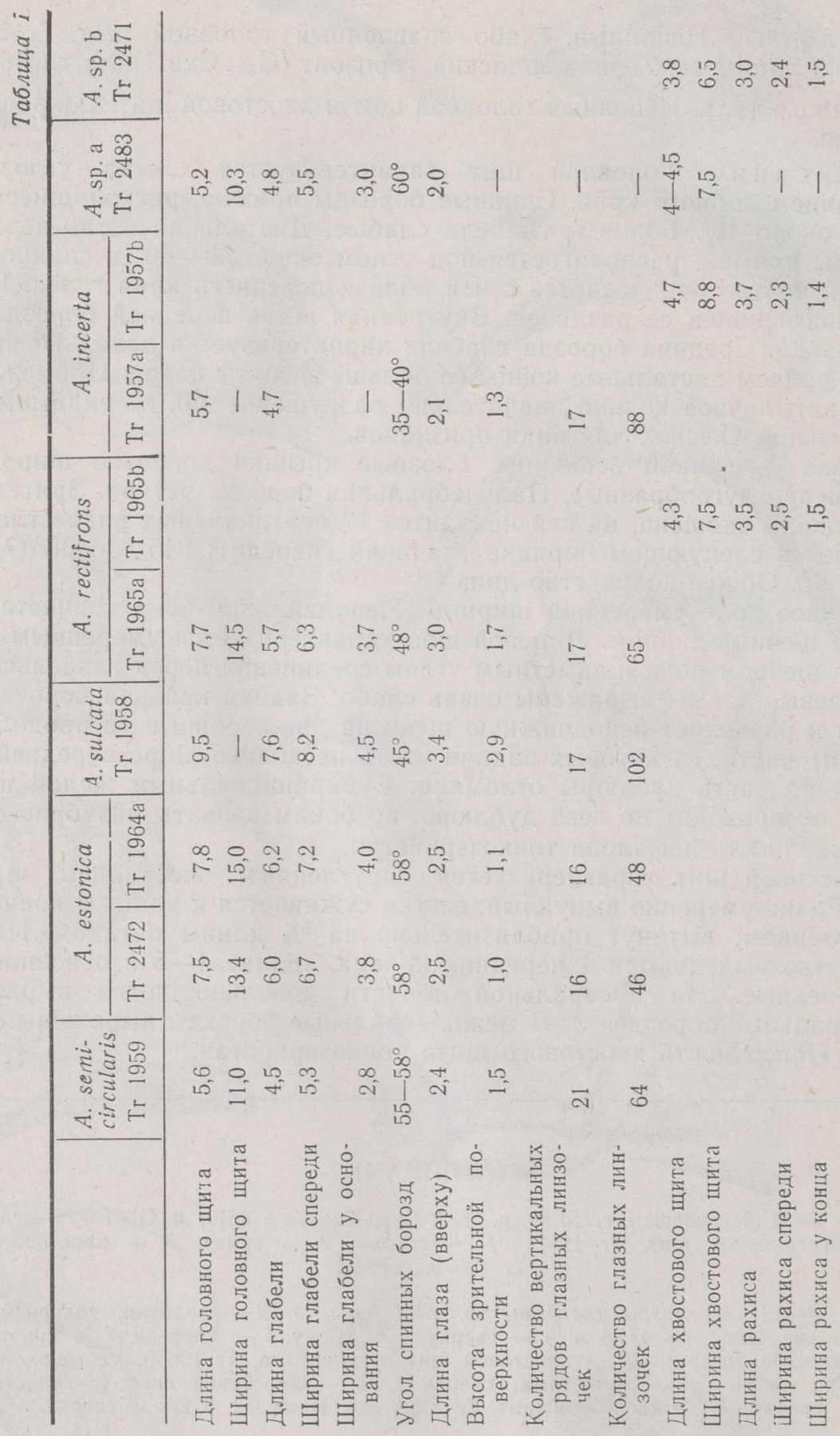


C р а вн ен ие. Описываемый вид сходен с Acernaspis sulcata sp. n., от которого отличается прежде всего слабовыраженным субкранидиальным желобом, бслее широкой глазной крышкой, несколько иным распольжением борозд глабели и небольшим углом между спинными бороздами.

М ес т он а хо жд ен и е. Скв. Икла, гл. 461,4 м. Средннй лландовери, райккюлаский горизонт $\left(\mathrm{G}_{3}\right)$, вероятно, низы зоны Demirastrites triangulatus.

\section{Acernaspis sp. a}

(табл. I, фиг. 13-15)

М а те р и ал. Два неполных спинных щита (у одного экземпляра головной щит отделен от остальной части щита). Сохранность довольно плохая.

О пи сани е. Глабель слабо выпуклая, по очертанию почти пятиугольная. Спинные борозды прямые, неглубокие и узкие, расходятся под углом около $60^{\circ}$. Борозды глабели полностью не сохранились. Боковая ветвь передней борозды глабели располагается под углом около $45^{\circ} \mathrm{k}$ спинным бороздам. Затылочное кольцо приподнято выше глабели. Глазная крышка узкая, дугообразная; пальпебральная борозда четкая. Неподвижные щеки вытянуты назад и кончаются под прямым углом заострениями.

Задняя краевая борозда длинная, четкая, разделяет неподвижную щеку на две неровные по ширине (в продольном сечении) части, из которых задняя часть значительно шире передней.

Туловище умеренно выпуклое, количество сегментов 11. Рахис широкий, составляет около $1 / 3$ всей ширины туловища. Борозды между кольцами и сочленовными полукольцами довольно глубокие. Плевральные борозды длинные, вытягиваются приблизительно на $2 / 3$ длины плевры (в поперечном сечении). Дистальные концы плевр с округленными задними частями изогнуты вперед.

Хвостовой щит имеет очертания округленного треугольника. Рахис вытягивается приблизительно на $4 / 5$ длины пигидия и состоит из 8 - 9 колец, из которых ясно выражены первые 5. На плевральной лопасти различаются 4 плевральные борозды, из которых 3 передние длинные, четвертая короткая и слабо выражена.

С р а внени е. Описываемый вид больше всего сходен с $A$. estonica sp. п. и $A$. sulcata sp. n., но отличается от них в основном узкими глазными крышками и длинными, резкими задними краевыми бороздами, ксторые разделяют неподвижные щеки на две значительно неравные части. Acernaspis sp. а представляет собой, вероятно, самостоятелыный вид, но ввиду плохой сохранности имеющегося материала мы пока не настаиваем на выдвижении нового вида.

М естон ах ожд ен и е. Пос. Кильтси. Нижний лландовери, верхняя часть юуруского горизонта $\left(\mathrm{G}_{1-2}\right)$.

Acernaspis sp. b

(табл. I, фиг. 11-12)

М а тери ал. Два хвостовых щита отличной сохранности.

О пи с ание. Широкоокругленный хвостовой щит с выступающим и довольно широким рахисом. Колец рахиса 8, из которых ясно выражены первые 4. Рахис кончается на расстоянии $4 / 5$ длины пигидия закруглен- 
ным концом. Различаются 4 плевральные борозды. Поверхность пигидия тонкозернистая.

3 а мечани е. Отличается от известных пигидиев представителей рсда Acernaspis Эстонии и принадлежит либо виду A. semicircularis sp. п., либо какому-то еще неописанному виду.

М естон ахождени е. Скв. Лаэва, гл. 136,1 м. Нижний лландовери, юуруский горизонт $\left(\mathrm{G}_{1-2}\right)$.

В табл. 1 даны размеры (в мм) изученных экземпляров новых, описанных в данной статье видов рода Acernaspis.

\section{ЛИТЕРАТ У РА}

Қ альо Д., Вингиса ар П. 1969. О разрезе райккюлаского горизонта на южной окраине Әстонии. Изв. АН ЭССР, Хим. Геол., 18, № 3.

C a mp bell K. S. W. 1967. Trilobites of the Henryhouse formation (silurian) in Oklahoma. Geol. Survey, Bull., 115.

S ch m i d t Fr. 1881. Revision der ostbaltischen silurischen Trilobiten, Abt. I, Phacopiden, Cheiruriden und Encrinuriden. Mem. Acad. Imp. Sci. St.-Petersb., Ser. VII, XXX, Nr. 1.

Sch m i d t Fr. 1907. Revision der ostbaltischen silurischen Trilobiten, Abt. VI. Allgemeine Ubersicht mit Nachträgen und Verbesserungen. Mem. Acad. Imp. Sci. St.-Petersb., Ser. VIII, XX, Nr. 10.

Институт геологии

Академии наук Эстонской ССР
Поступила в редакцию

$7 / \mathrm{N} 1969$

\section{REET MÄNNIL}

\section{EESTI ALAM- JA KESKLÄNDOUVERI TRILOBIITE PEREKONNAST ACERNASPIS}

Perekonnast Acernaspis oli Eestis esinenud vaid üksikuid leide. Viimastel aastatel on meil aga peamiselt puuraukudest saadud mitmeid uusı leide, milledest käesolevas kirjeldataksé alamländouverist pärineva nelja uue liigina $A$. semicircularis't, $A$. estonica't, $A$. sulcata't ja $A$. rectifrons'i ja keskländouverist pärinevat $A$. incerta't. Peale nende kirjeldatakse leide $A$. sp. a ja $A$. sp. b.

\section{REET MÄNNIL}

\section{ESTONIAN LOWER AND MIDDLE LLANDOVERIAN TRILOBITES OF THE GENUS ACERNASPIS}

Up to the recent times, only some single finds of Acernaspis had been known in Estonia, referred to by Fr. Schmidt $(1881,1907)$ as "Phacops" elliptifrons. In recent years, however, a number of additional finds were made, mostly in connection with new borings. In the new material, some species are represented by single specimens, only, but they are mostly in a good state of preservation and belong to definite stratigraphic levels. In the present paper, five new species of the Lower and Middle Llandoverian are described.

\section{Acernaspis semicircularis sp. $\mathrm{n}$.}

(Pl. I, Figs. 1-5)

Anterior margin of cephalon semicircular. Axial furrows deep and wide with angle of divergence $58^{\circ}$. The distal portion of the anterior glabellar furrow slightly curved, situated near the axial furrow. Middle glabellar furrow long and almost straight, begins near the axial furrow. Occipital ring provided with mesial tubercle. Eyes high, situated backwards. Palpebral lobes wide, palpebral furrows possess 64 lenses, situated in 21 vertical rows. Genae rather wide, genal angle pointed. Vincular furrow continuous, moderately strong anteriorly and notched laterally.

Viljandi boring, $231,4 \mathrm{~m}$. Lower Llandoverian, Juuru Stage $\left(\mathrm{G}_{1-2}\right)$. 


\section{Acernaspis estonica $\mathrm{sp} . \mathrm{n}$.}

(Pl. I, Figs. 6-10)

Slightly inflated glabella with subpentagonal outline. The angle of divergence of axial furrows on cephalon $58^{\circ}$. Distal portion of anterior glabellar furrow slightly curved, situated at an angle of $45^{\circ}$ in respect to axial furrow. Middle glabellar furrow long, almost straight, perpendicular to axial furrow. Eyes small, palpebral lobes low and wide. There are 46-48 eye lenses, placed in 16 vertical rows. Genae long, genal angle pointed. Vincular furrow continuous, notched laterally.

Abja boring, $310.2-316.0 \mathrm{~m}$. Lower Llandoverian, Juuru Stage $\left(\mathrm{G}_{1-2}\right)$.

\section{Acernaspis sulcata sp. n.}

(P1. II, Figs. 12-16)

Anterior margin of cephalon obtuse-angled. Angle of divergence of axial furrows $45^{\circ}$. Distal portion of the anterior glabellar furrow begins near the axial furrow, forming an angle of about $45^{\circ}$; the proximal tip widened. Proximal portion of the anterior glabellar furrow and the middle furrow are curved backwards. Eyes big, palpebral lobes narrow. The eye surface contains 102 lenses, situated in 17 vertical rows. Genal region moderately wide, genal angles pointed. Vincular furrow continuous, notched laterally.

Viljandi boring, $265.0 \mathrm{~m}$. Lower Llandoverian, Juuru Stage $\left(\mathrm{G}_{1-2}\right)$.

\section{Acernaspis rectifrons sp. $\mathrm{n}$.}

$$
\text { (P1. II, Figs. 4-11) }
$$

Slightly inflated glabella with anterior margin forming a gently curved line. Axial furrows rather wide and deep, divergence angle $48^{\circ}$. Distal portion of anterior glabellar furrow at an angle of ca $45^{\circ}$ in respect to axial furrow, straight, widening in the proximal part. Proximal portion of anterior furrow and middle furrow more bent at proximal ends. Eyes high, palpebral lobes wide. On the eye surface 65 lenses in 17 vertical rows. Genae wide, genal angles pointed. Vincular furrow continuous, weak anteriorly, notched laterally.

Ikla boring, 472.8-474.6 m. Lower Llandoverian, Raikküla Stage $\left(\mathrm{G}_{3}\right)$, zone of Pristiograptus cyphus.

\section{Acernaspis incerta $\mathrm{sp} . \mathrm{n}$.}

(P1. II, Figs. 1-3)

Anterior margin of glabella obtuse-angled. Distal portion of anterior glabellar furrows straight, beginning near axial furrow and proceeding at an angle of $40^{\circ}$ in respect to the latter, branching into two parts at the proximal end. Middle glabellar furrow strongly curved, especially at the distal end. Eyes moderate in size. Eye surface containing 88 lenses in 17 vertical rows. Genal angle pointed. Vincular furrow continuous, weak anteriorly, notched laterally.

Ikla boring, $461.4 \mathrm{~m}$. Middle Llandoverian, Raikküla Stage $\left(\mathrm{G}_{3}\right)$.

\section{Acernaspis sp. a \\ (Pl. I, Figs. 13-15)}

Weakly inflated glabella with obtuse-angled anterior margin. Angle of divergence of axial furrows on cephalon $60^{\circ}$. Distal portion of anterior glabellar furrow placed at an angle of $45^{\circ}$ in respect to axial furrow. Palpebral lobe narrow, palpebral furrow well defined. Fixigena pointed, extending backwards. Posterior border furrow long, dividing fixigena into two unequal parts in width (sag.), the posterior part being considerably wider.

Kiltsi. Lower Llandoverian, upper part of Juuru Stage $\left(\mathrm{G}_{1-2}\right)$.

$$
\begin{aligned}
& \text { Acernaspis sp. b } \\
& \text { (Pl. I, Figs. 11-12) }
\end{aligned}
$$

Pygidium with wide rounded posterior margin and wide relieved axis. Axial rings - 8 , the first 4 being well defined. 4 pleural furrows discernible.

Laeva boring, $136.1 \mathrm{~m}$. Lower Llandoverian, Juuru Stage $\left(\mathrm{G}_{1-2}\right)$. 